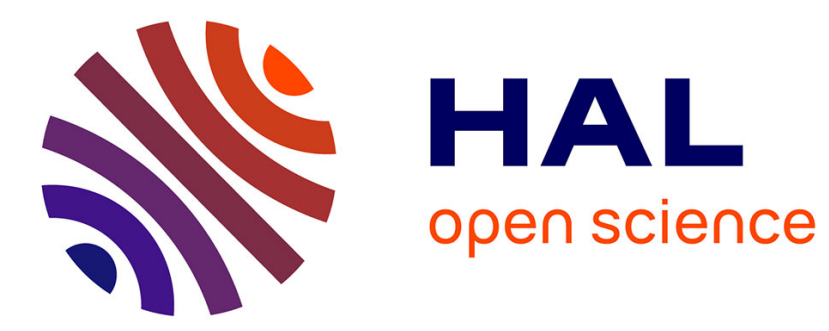

\title{
Critical review on lithium-ion batteries: are they safe? Sustainable?
}

\author{
Alain Mauger, C.M. Julien
}

\section{To cite this version:}

Alain Mauger, C.M. Julien. Critical review on lithium-ion batteries: are they safe? Sustainable?. Ionics, 2017, 10.1007/s11581-017-2177-8 . hal-01558209

\section{HAL Id: hal-01558209 \\ https://hal.sorbonne-universite.fr/hal-01558209}

Submitted on 11 Jul 2017

HAL is a multi-disciplinary open access archive for the deposit and dissemination of scientific research documents, whether they are published or not. The documents may come from teaching and research institutions in France or abroad, or from public or private research centers.
L'archive ouverte pluridisciplinaire HAL, est destinée au dépôt et à la diffusion de documents scientifiques de niveau recherche, publiés ou non, émanant des établissements d'enseignement et de recherche français ou étrangers, des laboratoires publics ou privés. 


\title{
Critical review on lithium-ion batteries: are they safe? Sustainable?
}

\author{
A. Mauger ${ }^{1}$, C.M. Julien ${ }^{2}$ \\ ${ }^{1}$ Sorbonne Universités, UPMC Univ Paris 06, Institut de Minéralogie, de Physique des Matériaux et de \\ Cosmochimie (IMPMC), CNRS UMR 7590, 4 place Jussieu, 75005 Paris, France \\ ${ }^{2}$ Sorbonne Universités, UPMC Univ Paris 06, Physicochimie des Electrolytes et Nanosystèmes \\ Interfaciaux (PHENIX), CNRS UMR 8234, 4 place Jussieu, 75005 Paris, France
}

Keywords: Lithium-ion batteries. Safety aspects. Cathode materials. Anode materials. Electric vehicles. Smart grid

\begin{abstract}
The goal of this critical review is to explain why the safety problem raised by the lithium batteries must be considered. The performance of the batteries with different chemistries is compared and analyzed, with emphasis on the safety aspects, in addition to the electrochemical properties of the cells. Problems encountered with cathode materials (layered compounds, spinel and olivine), anode materials (graphite and lithium titanate), electrolytes, lithium salts, and separators are pointed out. In this critical review, we also discuss the place of the lithium batteries in the context of sustainable energies (electric vehicles, smart grid).
\end{abstract}




\section{Introduction}

Research in lithium batteries started in 1912 when Gilbert N. Lewis took his position of professor of physical chemistry and dean of the College of Chemistry at the University of California Berkeley. The first primary lithium batteries came onto the market in the 1970s. Two other decades passed before Sony Energytec commercialized the first rechargeable Li-ion battery in 1990 [1]. This battery was equipped with a $\mathrm{LiCoO} 2$ cathode element, and the anode was graphitic carbon. Soon after, one of these Li-ion batteries (LIBs) exploded in hand- held video cameras. Since then, the safety issue associated to the risk of thermal runaway and battery fire is known to be a major problem of the lithium batteries. This is also costly. For instance, Dell in 2006 had to recall 4.1 million notebook computer Sony batteries because of battery fires with an estimated cost of $300 \mathrm{M} \$$ (see Fig. 1). The second problem of concern was (and is still) to increase the energy and power densities for use in a first step for portable use and in a second step for hybrid electric vehicles (HEVs) and electric vehicles (EVs). The need for the development of the so-called green energy has been understood since a long time by scientists. What is rather new, however, is the awareness of the governments across the world that the development of the green energy and reduction of greenhouse gas was mandatory and an emergency. Actually, the increase in the number of people on earth combined with the increase in consumption of energy per person resulting from an increase in the nominal GDP per capita at the scale of the planet implies inevitably an enormous increase in energy consumption for the years to come. In this context, electrochemical energy storage has become a major issue. In particular, LIBs can solve the intermittence problems of sustainable energy by leveling the production of electricity by windmills or solar cells. Electric vehicles do not emit gas and are then considered as "clean".

These considerations, plus the huge development of cell phones and personal computers explains that the market of the lithium-ion batteries that raised to US\$ 11.7 billion in 2012 is predicted to increase to US\$ 33.1 billion in 2019. This fast increase in the market and the big money that it generates has attracted the envy of companies and a fierce competition between them, to make the battery with the highest energy density and/or the highest power density. The scientists also feel this pressure. Occasionally, some of them who want to be famous or simply run after grants cannot resist to the temptation to write, preferentially in journals that have a top impact factor, papers that are closer to journalist scoops than scientific works. This is, however, unfortunate, because the decision makers may take for a scientific result what is a misleading advertising. That is why it is useful sometimes to write a critical review on the state-of-the-art of the lithium batteries and discuss what hope can we place in them in the near future. We have recently published a review on the state- of-the-art in the research on all the elements of the lithium-ion batteries in a book [2]. The purpose here is different, namely focus 
attention on the batteries that are already commercialized, and make a critical analysis to separate between what we can expect from them on a scientific basis, and what belongs to deceptive or misleading commercial advertising. Most of the batteries that are commercialized have graphitic carbon as the active positive electrode. However, a new battery with lithium titanate (LTO) positive electrode has been recently commercialized (https://www.ev-power.eu/LTO-Cells/) and finds a fast increasing market. On another hand, many active materials are available for negative electrodes and play such an important role that the LIBs are commonly identified by them.

The active elements of the commercial electrodes are powders made of particles of typical size $100 \mathrm{~nm}$. This nano-size is required to increase the effective surface area in contact with the electrolyte, which in turn increases the rate capability of the battery. However, the drawback is an increased sensitivity to the chemical reaction of the powder with the electrolyte, which may cause a safety problem. When carbon is used as the negative electrode, the electrolyte is a mixture of carbonates (ethylene carbonate plus diethyl- or dimethyl carbonate). This is mandatory to form a stable passivation layer called solid-electrolyte interface (SEI) at the surface of the carbon. Due to the presence of carbonate, the electrolytes are very flammable. Moreover, the SEI is resistive, which may generate heat during operation. Therefore, both the electrolyte and the SEI are other elements playing a role in the safety issues. The separator is also an important element to take into consideration. Therefore, all the elements entering the composition of the batteries turn out to be play an important role to avoid thermal runaway of the batteries. Many industrials, but also some scientists that have a consulting activity, consider that the intrinsic safety of the battery is not so important, since the battery monitoring system (BMS) can be so efficient that it is able to prevent any problem. Recent battery fires show that this view is too optimistic.

In this paper, we explain (in the first section) why the safety problem raised by the lithium batteries must be considered. In the second section, the performance of the batteries with different chemistries is compared and analyzed, with emphasis on the safety aspects, in addition to their electrochemical properties. A critical review of the results is reported, and the place of the lithium batteries in the context of sustainable energies is discussed.

\section{The safety concern}

Fifty kilowatt-hours, which is the typical capacity for a battery to power an electric car (the maximum is $80 \mathrm{kWh}$ in a Tesla car), is an energy equivalent to $4.3 \mathrm{~kg}$ of TNT or $3.44 \mathrm{~kg}$ of dynamite, i.e., 18 dynamite sticks. The comparison is actually meaningful, because a single cell usually takes fire, but a pack is made of a lot of cells, and by chain reaction it can explode. Nobody would want to sit on such 
an amount of TNT or dynamite in its car; however, people usually do not care about such an energy stored in the battery of their electric car. One argument commonly delivered by auto-makers is that after all, the energy stored in the battery is still smaller than the energy stored in a gas tank. This comparison, however, is misleading, because gasoline cannot take fire in a tank: gasoline can be ignited when it is in the air at levels between 1.4 and $7.6 \%$ and the self-ignition temperature is larger than 200 ${ }^{\circ} \mathrm{C}$. These conditions are rarely met even in a car crash. However, a diesel truck and a diesel bus took fire instantaneously after a collision, killing 43 people in October 2015, in France. The battery fire of electric cars is unfortunately much more usual (but fortunately less deadly so far), and we will discuss why in the next sections.

The lithium salt added to the electrolyte is $\mathrm{LiPF}_{6}$. This choice is justified by the fact that it is highly conductive, and in addition it creates a passivation layer of $\mathrm{AlF}_{3}$ at the surface of the aluminum current collector, thus protecting the current collector against the corrosion of the electrolyte. The problem, however, is that this salt decomposes at temperature as small as $50{ }^{\circ} \mathrm{C}$, especially with carbonate-based electrolytes [3]. In case of battery fire, the products resulting from the decomposition of the salt and the organic elements of the electrolyte interact with the oxygen released at the positive electrode so that at the end, a 50-kWh battery releases $6 \mathrm{~kg}$ of $\mathrm{HF}+\mathrm{Po}_{\mathrm{x}} \mathrm{H}_{\mathrm{y}}$. HF is reacting very fast with other products, but the $\mathrm{Po}_{\mathrm{x}} \mathrm{H}_{\mathrm{y}}$ gas is toxic, as it provokes irreversible neuronal damage, possibly lethal at the dose of $83 \mathrm{mg} \mathrm{m}^{-3}$ in air. The battery fires are thus quite dangerous, as they can burn the user, and even intoxicate people around them.

\section{The origin of the battery fires}

\section{The positive electrodes}

Some of the most popular Li-ion technologies developed so far are reported in Table 1 taken from [2] with the acronym that will be used hereunder. The four first ones belong to the same family of lamellar compounds; the next one is the LiMn2O4 spinel; the last one is the olivine LiFePO4.The properties of these materials depend greatly on the crystal geometry, so that they must be analyzed separately.

\section{Lamellar compounds}

After the explosion of $\mathrm{LiCoO}_{2}$ (LCO)-based batteries in hand-held video cameras, it was understood that another material with a better thermal stability should be found, by partial substitution of $\mathrm{Co}$ with another transition metal: $\mathrm{Mn}$ and $\mathrm{Ni} \mathrm{LiNiO}_{2}$ (LNO) has been abandoned for several 
reasons.

(1) $\mathrm{Ni}^{3+}$ ions are in the low-spin state and thus provoke a Jahn-Teller distortion that destabilize the lattice [4]; (2) irreversible structural phase transitions occur during cycling [5]; (3) release of oxygen and safety concerns in the charged state [6]; (4) there is always a mixing of $\mathrm{Li}^{+}$and $\mathrm{Ni}^{3+}$

in the inter-slab space $[4,7]$. To reduce this cation mixing, Co is introduced in the matrix efficiently, as it stabilizes the layered structure in $\mathrm{LiNi}_{1-\mathrm{y}} \mathrm{Co}_{\mathrm{y}} \mathrm{O}_{2}[8]$. As a consequence, the electrochemical properties are improved. Nevertheless, the cobalt concentration must remain small, because the cobalt-rich materials tend to lose oxygen on deep lithium extraction [9]. That is why the composition $\mathrm{LiNi}_{0.8} \mathrm{Co}_{0.2} \mathrm{O}_{2}$ is commonly considered as the best compromise and was proposed for application in micro-batteries [10]. However, the compound exhibits crystal structure phase transitions similar to that of $\mathrm{LiNiO}_{2}$ during charge process, which results in a capacity fading. Also at $\mathrm{x}>0.5, \mathrm{Li}_{1-\mathrm{x}} \mathrm{Ni}_{0.8} \mathrm{Co}_{0.2} \mathrm{O}_{2}$ is a strong oxidizing agent due to the presence of $\mathrm{Ni}^{4+}$ ions, which can slowly cause the decomposition of the liquid electrolyte that results in the dangerous evolution of gases [11]. In addition, at $x>0.5$, the compound is structurally unstable when heated above $200{ }^{\circ} \mathrm{C}$ and evolves oxygen and decomposition products. Doping at the cobalt site can reduce these problems [12], in particular Al doping [13], which made the $\mathrm{Li}_{1-\mathrm{x}} \mathrm{Ni}_{0.8} \mathrm{Co}_{0.15} \mathrm{Al}_{0.15} \mathrm{O}_{2}$ (NCA) popular already 15 years ago. This $\mathrm{Al}$ doping, however, although it improves some chemical properties, did not solve the problems above mentioned. In particular, the differential scanning calorimetry (DSC) spectra of this electrode in Fig. 2 show that $\mathrm{Li}_{1-\mathrm{x}} \mathrm{Ni}_{0.8} \mathrm{Co}_{0.15} \mathrm{Al}_{0.15} \mathrm{O}_{2}$ is thermally unsafe, as this cathode undergoes its exothermic reaction with very large enthalpy $\left(941 \mathrm{~J} \mathrm{~g}^{-1}\right)$ between 200 and $250{ }^{\circ} \mathrm{C}$, much earlier than the onset of the exothermic reactions of other cathodes like spinel and lithium iron phosphate [14].

Due to the resulting propensity of battery fire, this $\mathrm{Li}_{1-\mathrm{x}} \mathrm{Ni}_{0.8} \mathrm{Co}_{0.15} \mathrm{Al}_{0.15} \mathrm{O}_{2}$ cathode has been rarely used during two decades. However, it was not possible to resist to the temptation to use it to take advantage of its high energy density resulting from its high capacity $\left(\sim 275 \mathrm{mAh} \mathrm{g}^{-1}\right)$ combined with high operating cell voltage $\left(4.3 \mathrm{~V}\right.$ vs. $\left.\mathrm{Li}^{+} / \mathrm{Li}^{0}\right)$, and $\mathrm{Li}_{1-\mathrm{x}} \mathrm{Ni}_{0.8} \mathrm{Co}_{0.15} \mathrm{Al}_{0.15} \mathrm{O}_{2}$ is currently in widespread commercial use despite the intrinsic safety concern. An illustration of the two aspects is provided by Tesla with its Sedan electric car: on the one hand, the car is sold for a range of $560 \mathrm{~km}$ owing to the high energy density of such batteries. On the other hand, it experiences battery fires. The 7th of them is shown in Fig. 3 (Oslo, January 2016). The 8th one was in Bayonne, France, in August 2016. Unfortunately, two people burnt in their car in Indianapolis in the 9th fire in November 2016 when the battery took fire after a car accident. More recently, in March 2017, one of them burnt in Shanghai, 
another one in Yorkshire.

Due to the high risk of thermal runaway of the batteries above mentioned, Mn has been introduced to stabilize the lattice and $\mathrm{Ni}$ concentration decreased. $\mathrm{LiNi}_{1-\mathrm{x}-\mathrm{y}} \mathrm{Mn}_{\mathrm{x}} \mathrm{Co}_{\mathrm{y}} \mathrm{O}_{2}(\mathrm{NMC})$ has been proposed in 1999 [15]. Soon after, attention has been focused on $\mathrm{LiNi}_{\mathrm{y}} \mathrm{Mn}_{\mathrm{y}} \mathrm{Co}_{1-2 \mathrm{y}} \mathrm{O}_{2}[16$, 17], i.e., compounds with the same concentration of $\mathrm{Ni}$ and $\mathrm{Mn}$, because in that case, the ions are in the $\mathrm{Ni}^{2+}$, $\mathrm{Mn}^{4+}, \mathrm{Co}^{3+}$ valence state, so that the presence of the Jahn-Teller $\mathrm{Ni}^{3+}$ is avoided. Therefore, the presence of manganese is here to stabilize the lattice, the cobalt is here to avoid the cation mixing (nickel on lithium site), and nickel is the active element in the electrochemical process, by switching from the $\mathrm{Ni}^{2+}$ state to the $\mathrm{Ni}^{3+}$ and the $\mathrm{Ni}^{4+}$ state upon lithium extraction [18]. Note, however, that even though there is no $\mathrm{Ni}^{3+}$ ions in the initial (discharged) state, the delithiation process immediately generates them, so that the advantage in terms of thermal stability upon cycling is not evident. Therefore, we have measured the self-heating of a 18650 cell with this cathode, with an accelerating rate calorimeter (ARC) [14]. The results are reported in Fig. 4. Indeed, we find that the self-heating becomes important above $220{ }^{\circ} \mathrm{C}$. This temperature is not normally reached inside a cell, but it can be reached if there is a local defect inside the cell, or in a nail penetration test or a crush test. Another source of heating may be due to the resistive solid-electrolyte interface (SEI) formed at the surface of the particles [19]. To overcome this effect, many attempts have been made to coat $\mathrm{NMC}$ with metal oxides such as $\mathrm{Al}_{2} \mathrm{O}_{3}, \mathrm{TiO}_{2}, \mathrm{ZrO}_{2}, \mathrm{MgO}$, or other compounds such as $\mathrm{FePO}_{4}, \mathrm{LiFePO}_{4}$, and $\mathrm{Li}_{4} \mathrm{Ti}_{5} \mathrm{O}_{12}$ (see [20] for a review), and more recently poly(tris(2-(acryloyloxy)ethyl)phosphate) [21] without solving entirely the problem. In this last case, the authors were also too optimistic when claiming that it suppressed the exothermic reaction: it only shifted the exothermic peak temperature from 294 to $284^{\circ} \mathrm{C}$, and reduced the peak from 649 to $576 \mathrm{~J}$ $\mathrm{g}^{-1}$.

We can thus conclude that, on a general basis, these lamellar compounds cannot be considered as intrinsically safe. Another experimental evidence, more costly than the ARC measurements, was provided by the choice of Boeing to equip its Dreamliner. In 2013, the thermal runaway of the batteries manufactured by GS Yuasa led the US Federal Aviation Administration to ground the entire 787 fleet of 50 jets until safety retrofit (see Fig. 5). The estimated cost was 1 billion dollars. Fortunately, the planes went on fire at or close to an airport rather than over the middle of the Pacific or Atlantic Ocean. The incident, however, was perfectly predicted by scientists, but none of them was heard.

In addition, the NMC batteries do not have a long life. The NMC//carbon lithium-ion battery from a mass-production line shows a two-stage capacity loss [22]. In the first stage, the battery capacity slowly ages due to a loss of lithium associated to the thickening of the SEI; then the battery enters the 
second stage with a much higher degradation rate due to the loss of NMC material.

$\operatorname{LiMn}_{2} \mathrm{O}_{4}$

$\mathrm{LiMn}_{2} \mathrm{O}_{4}(\mathrm{LMO})$ is a material that belongs to the 4-V intercalation hosts. It has several advantages with respect to the lamellar compound family. In particular, it avoids the cobalt, which is expensive and toxic; moreover, the awful conditions of extraction of cobalt in the Republic of Congo by children is regularly denounced by Amnesty International and the International NGOs. In addition, its thermal stability is much better than that of the lamellar compounds (see Figs. 2 and 3) at high temperature. It has, however, some disadvantages. It transforms to a tetragonal phase when inserting more lithium than $1 \mathrm{Li}$ per $\mathrm{Mn}$ and this transformation is accompanied with large volume change resulting in capacity fade. Therefore, the cycling must be limited to the domain $\lambda-\mathrm{MnO}_{2}-\mathrm{LiMn}_{2} \mathrm{O}_{4}$, which limits the theoretical specific capacity to $148 \mathrm{mAh} \mathrm{g}^{-1}$, but $120 \mathrm{mAh} \mathrm{g}^{-1}$ in practice. Yet it does not solve entirely the problem because the formation of tetragonal $\mathrm{Li}_{2} \mathrm{Mn}_{2} \mathrm{O}_{4}$ has been observed at the surface of the LMO particles due to local conditions of discharge [23], which results in aging of the battery. The main source of aging, however, is the dissolution of manganese into the electrolyte, due to the disproportionation of $\mathrm{Mn}^{3+}$ into $\mathrm{Mn}^{2+}$ and $\mathrm{Mn}^{4+}$ [24]. Of course, as any chemical reaction, this dissolution accelerates with temperature. Note this is well-known since 1996. However, the Leaf of Nissan was first commercialized in December 2010 in the USA (in 2011 in other countries) with LMO batteries. Of course, after a hot summer in the USA, the batteries fell down because of the dissolution of manganese, forcing Nissan to recall the Leaf cars to replace the batteries. This is another example where either the car makers fail to ask advice to scientists, or do not take their advice into account. The solution to reduce this aging problem was to mix the LMO powder with another active element that would prevent, or at least postpone the dissolution of manganese of LMO alone. This other element can be NMC. Indeed, Dubarry et al. [25] tested a lithium-ion battery with $\mathrm{LiMn}_{1 / 3} \mathrm{Ni}_{1 / 3} \mathrm{Co}_{1 / 3} \mathrm{O}_{2}+\mathrm{LiMn}_{2} \mathrm{O}_{4}$ cathode and carbon anode and found the same two-stage capacity loss process as we have already mentioned for NMC alone. However, in this case, the second stage occurred almost at the end of the life of the battery, so that it could be neglected. Therefore, the mixing of NMC and LMO powders (i.e., blends) reduced significantly the dissolution of the active cathode elements and is a good solution to improve the life of the battery. This is the solution that has been adopted by LG Chem. in South Korea, which provides the batteries of the electric cars of Renault. The drawback, however, is that we add to the thermally stable LMO an element NMC that is less stable in the process, so that the intrinsic safety of the battery is again degraded. The next step is then to investigate the thermal stability of the mixed 
powder as a function of the proportion of NMC in the composite, which has not been done yet to our knowledge.

Another solution has been to mix LMO with Al-doped $\mathrm{LiNiO}_{2}$. This has been the choice of Automative Energy Supply Corporation (AESC), the company that manufactures the batteries of the Nissan Leaf. Two reasons can motivate this choice. (1) It is well-known that Al substitution of the transition-metal cation of lithium intercalation oxides increases the cell voltage [26]. We will show in the next section that this just results in a propensity to loose oxygen, and thus to battery fire. (2) It has been reported that $\mathrm{Al}$ doping of $\mathrm{LiNiO}_{2}$ has a beneficial effect on the thermal stability in the charged state [27]. However, the comparison between Al-doped and undoped samples can be done by comparing the differential scanning calorimetric spectra only at the same state of charge. In [27], the

highest state of charge in common between the Al-doped $\mathrm{Li}_{1-\mathrm{x}} \mathrm{Al}_{1 / 4} \mathrm{Ni}_{3 / 4} \mathrm{O}_{2}(20.5 \mathrm{mg})$ and undoped $\mathrm{Li}_{1-\mathrm{x}} \mathrm{NiO}_{2}(16.6 \mathrm{mg})$ materials is $\mathrm{x}=1 / 2$, in which case the peak of heat flow is about $3 \mathrm{mWin}$ both cases, located at 180 and $200{ }^{\circ} \mathrm{C}$ for the undoped and Al-doped samples, respectively. The gain in thermal stability is thus not spectacular. Therefore, the choice that has been made by AESC poses a safety concern. The surface of Al-doped $\mathrm{LiNiO}_{2}$ can be coated with a NMC layer to improve cycle characteristics thereof [28], but this is not done in the commercial batteries.

\section{$\mathrm{LiFePO}_{4}$}

$\mathrm{LiFePO}_{4}(\mathrm{LFP})$ is a material that crystallizes in the olivine structure shown in Fig. 6. At first sight, it would look like a lamellar compound. This, however, is not true, because the Fe-O planes are strongly bound by $\mathrm{PO}_{4}$ bridges. As a result, LFP has a remarkable thermal stability (see Fig. 2). The operating voltage with the graphite anode is $\sim 3.2 \mathrm{~V}$, lower than the $4 \mathrm{~V}$ of the previous cathode elements reported above, like LMO. The specific capacity that is reached experimentally is about $160 \mathrm{mAh} \mathrm{g}^{-1}$ close to the theoretical value $\left(170 \mathrm{mAh} \mathrm{g}^{-1}\right)$, which is larger than the experimental capacity of LMO electrodes, so that the energy density, product of the capacity by the voltage, is not much different, however. The major advantage of LFP is the safety. Owing to its thermal stability, the LFP//graphite cell has a major advantage: it passes all the tests (nail penetration, crush tests, short circuit and any other mechanical test or tolerance on abuse) without thermal runaway. If safety is the main concern, which is the case for automotive applications, this is the best cathode element, and indeed, it occupies a part of the market. China's shipment of LFP totaled 32,400 tons in 2015,65\% of the worldwide market, and is expected to attain 236,000 tons in 2020 with the proportion increasing to $76 \%$ 
(http://www.chinamarketresearchreports.com/115148.html). This report profiles 16 LFP materials manufacturers and 11 LFP battery companies. The low energy density of lithium iron phosphate batteries restricts the EV's driving range, a situation that makes some enterprises turn to NMC, in particular in the USA, in Japan, and in Korea, despite the safety concern outlined above. However, the use of LFP in energy storage, photovoltaic and communication batteries is on the rise, the reason for its huge development.

LFP is a very bad electrical conductor, but the coating with conductive carbon has solved this problem. Dealing with nanoparticles, the electron path inside the LFP material is small, and once it has reached the surface of the particle, the electron is driven to the current collector by the conductive carbon that percolates through the structure. The cathode active element is always carbon-coated lithium iron phosphate (C-LFP).

Owing to the stability of LFP in operating conditions, this compound can be used as a coating layer to protect cathode elements of the 4-V family, but also cathode elements of the 5-V family that are not yet commercialized but are the subject of intense research. We ourselves proposed such a solution that was beneficial to the electrochemical properties for both for 4V[29] and 5V [30] cases. Note that the particles are always multi-composites in that case, since the LFP coat must be itself coated with carbon. However, the hope that we can put in this procedure should be tempered, because the upper charge limit of the LFP battery for full state of charge is typically $3.6 \mathrm{~V}$. Therefore, as the potential is raised above $4 \mathrm{~V}$, the LFP coat is in overcharge. However, we can see in Fig. 4 that the thermal properties of the LFP cell in overcharge are degraded to the point that they are barely better than those of LMO. Since the proportion of LFP in the coat is not large, this might not be a problem, but at least, further investigation of the thermal behavior of C-LFP-coated or mixed powders with CLFP as one component should be done before we can conclude.

Attention must be cared on the fact that LFP must be synthesized free of impurity. Otherwise, the performance is degraded. The studies of the LFP//graphite commercial A123 18650 cells at a 1C rate showed that an overcharge does not result in a thermal runaway, but it resulted in a battery failure [31]. The reason was that the impurities containing iron in the raw material led to dendrite formation, responsible for micro-shorting because of the wider reduction voltage range in the overcharge process [32]. In relation to this side effect of impurities, we have shown in a prior work that metallic nanosized $\mathrm{Fe}_{2} \mathrm{P}$ impurities form spontaneously when the sintering temperature used during the synthesis is too high[33]. There is no dissolution of Fe coming from LFP in the electrolyte, but the iron contained in $\mathrm{Fe}_{2} \mathrm{P}$ dissolves into the electrolyte and causes such problems [34]. Otherwise, it is a temptation to add 
$\mathrm{Fe}_{2} \mathrm{P}$ impurities on purpose as an alternative to carbon coating $[35,36]$, because these impurities are metallic and thus increase the electrical conductivity of the LFP powder, which is beneficial to the rate capacity. However, this is true only on a short term basis, and we have repeatedly warned the manufacturers that the presence of such Fe-rich phosphide metal impurities liberates $\mathrm{Fe}$ in the electrolyte, and at the end reduces the life of the battery [37].

In another attempt to avoid the carbon some authors claimed that they had doped LFP by a range of aliovalent transition-metal ions [38]. This, however, is not true [39]. Moreover, theoretical calculations of dopant substitution energies for cations indicate supervalent doping on either Li or M $(\mathrm{M}=\mathrm{Fe}, \mathrm{Mn})$ sites (M1 and M2 sites, respectively) is energetically unfavorable and does not result in an increase in electronic conductivity [40,41]. As a matter of fact, the aliovalent ions reside primarily on the M1-(Li) site. Moreover, the aliovalent ion charge is balanced by lithium vacancies, with the total charge on the iron site being exactly +2.000 not indicating enhanced electronic conductivity [42], so that the aliovalent ion is actually not a dopant. The increase in conductivity wrongly attributed to doping in the past was due either to a carbon coating owing to the carbon that was present among the precursors [43], or the formation of a net- work of metal-rich phosphide (and we have just seen that it reduces the life of the battery) [44] or simply metallic nano-particles of the aliovalent element that did not enter into the matrix. The conclusion is that there is no option but coating the LFP particles with a conductive element, and carbon is the best choice, because of the affinity between iron and carbon that makes the carbon coating very easy.

Another advantage of LFP is the high rate capability. This led some authors to make a scoop by announcing in Nature an impossibly high recharging rate capability for a LIB of $9 \mathrm{~s}$ [45]. We have denounced this scoop [46], because it would be deceptive for those less experienced in LIB technology, who might think that if it is published in Nature, it is true. Actually, it is impossible to reach very fast charging with graphite anodes, because if too many lithium ions arrive at the same time on the carbon anode, there is a traffic jam: the $\mathrm{Li}^{+}$ions do not have time to penetrate between the graphene sheets, and they accumulate at the surface to form what is called "Li plating", which is actually dangerous for the battery. Fast charging can be reached with another anode, $\mathrm{Li}_{4} \mathrm{Ti}_{5} \mathrm{O}_{12}$ as we shall see in the following section.

\section{The negative electrode}

Let us set the record straight. The full story of this anode starts in 1955 when Albert Herold, in Nancy, gave evidence of the insertion of lithium in graphite [47]. This was confirmed by the synthesis 
of $\mathrm{LiC}_{6}$ in 1965 [48]. The synthesis of $\mathrm{LiC}_{6}$, however, was not obtained by electrochemical process at that time, and the reversible intercalation of lithium in graphite up to $\mathrm{LiC}_{6}$ was established by Besenhard and Eichinger, who proposed this material as an anode in 1976 in lithium cell using Li salt dissolved in aprotic organic solvent, i.e., propylene carbonate (PC) or dimethyl sulphoxide (DMSO), as electrolyte $[49,50]$. Still the restriction of the use of the graphite as a cathode material at that time came from the lack of a suitable electrolyte, a problem that was solved by Michel Armand and Michel Duclot using a PEO-polymer electrolyte [51].

Graphite is still the most common anode in commercial Li-ion batteries. Indeed, carbon has attractive features. Graphite is a semi-metal with high electrical conductivity $10^{-3} \mathrm{Scm}^{-1}, \mathrm{LiC}_{6}$ is a metal that has a high ionic conductivity $10^{-8}-10^{-10} \mathrm{~cm}^{2} \mathrm{~s}^{-1}$. The theoretical capacity between $\mathrm{C}$ and $\mathrm{LiC}_{6}$ is 372 $\mathrm{mAh} \mathrm{g}^{-1}$. The potential of carbon with respect to Li metal is only $0.15-0.25 \mathrm{~V}$. This low potential is just good news to increase the operating voltage of the battery, but there is a drawback: the reaction with the electrolyte. Therefore, there is a need to control the formation of the SEI, and for this purpose, ethylene carbonate (EC) is needed in the electrolyte. Unfortunately, the flash point of EC is only 150 ${ }^{\circ} \mathrm{C}$. Therefore, we recover the paradigm already mentioned for the positive electrode, namely gain in energy density by increasing the voltage of the cell is detrimental to safety. Experiments have shown that commercial batteries containing graphite may reach their thermal runaway temperature between 160 and $180^{\circ} \mathrm{C}$ [52]. Even worse, the same authors concluded that in a battery where a graphite with a high BET surface area is used, the thermal runaway temperature could decrease to about $120^{\circ} \mathrm{C}$.

Today, $\mathrm{Li}_{4} \mathrm{Ti}_{5} \mathrm{O}_{12}$ (LTO) is the only anode that can be found as an alternative to graphite in commercial batteries. The voltage of LTO is $1.5 \mathrm{~V}$ with respect to $\mathrm{Li}^{+} / \mathrm{Li}^{0}$, which has an advantage: there is no SEI, which increases the safety. In addition, the rate capability is remarkable and much better than that of graphite, which removes the risk of Li plating and the safety problems associated to it. The cycling life is outstanding. These properties are due to the fact that the change of volume during lithium absorption or desorption is negligible. The only drawback with respect to graphite anode is a loss of energy density, since the voltage of the battery is $1.5 \mathrm{~V}$ smaller. That is why it is used in commercial batteries with a NMC counter-electrode (which again introduces safety concern). Owing to confidentiality the battery manufactures usually refuse to provide the battery internal parameters. Then the batteries must be tested in the lab. For NMC//LTO, this has been done in Ref. [53] at $55{ }^{\circ} \mathrm{C}$, not only a temperature where the batteries degrade more rapidly than at room temperature but also a temperature that can be reached in operation in an electrical vehicle. As a result, the NMC//LTO battery shows a two-stage capacity loss, like in the case of $\mathrm{NMC//graphite,} \mathrm{but} \mathrm{for} \mathrm{a} \mathrm{different} \mathrm{reason:} \mathrm{the}$ 
authors consider that, in the first stage, the battery capacity loss is mainly caused by the loss of anode material (instead of a loss of lithium associated to the thickening of the SEI in the case of the $\mathrm{NMC//graphite} \mathrm{cell} \mathrm{at} \mathrm{room} \mathrm{temperature)} \mathrm{and} \mathrm{the} \mathrm{capacity} \mathrm{loss} \mathrm{rate} \mathrm{is} \mathrm{lower.} \mathrm{In} \mathrm{the} \mathrm{second} \mathrm{stage,} \mathrm{the}$ battery capacity loss is mainly caused by the loss of cathode just like in NMC//graphite, and the capacity loss rate is higher. However, another explanation should prevail for the first-stage aging: aging of the electrolyte rather than a loss of anode material. At this temperature, the degradation of the $\mathrm{LiPF}_{6}$ salt in organic carbonate electrolytes generate $\mathrm{HF}$, yielding $1 \mathrm{mmol} \mathrm{L}^{-1}$ of $\mathrm{HF}$ in $1 \mathrm{~mol} \mathrm{~L}^{-1} \mathrm{LiPF}_{6}$

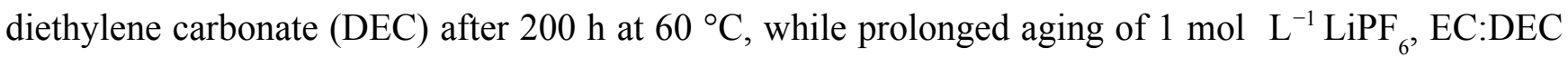
electrolyte at room temperature results in a significantly lower HF formation rate with time [54]. Therefore, the commercial Li-ion batteries equipped with this standard electrolyte should be kept at room temperature.

Another advantage of LTO is its rate capability. To fully take benefit of this property, it has to be coupled to a cathode that has similar properties, namely LFP. In particular a "18650" battery where the active element of the cathode was 90-nm-thick LFP nanoparticles coated with 2 wt.\% carbon, and the anode uncoated LTO particles of the same size delivers a capacity of $800 \mathrm{mAh}$. It retains full capacity after 20,000 cycles performed at charge rate $10 \mathrm{C}$ (6 $\mathrm{min})$, discharge rate $5 \mathrm{C}$ (12 min), and retains $95 \%$ capacity after 30,000 cycles at charge rate $15 \mathrm{C}(4 \mathrm{~min})$ and discharge rate $5 \mathrm{C}$ both at 100\% DOD and $100 \%$ SOC [55]. If the LTO particles are also carbon-coated, then the 18650 cell can be charged at 60C ( $1 \mathrm{~min}$ ) with $80 \%$ of rated capability, while the temperature in the cell does not exceed $40{ }^{\circ} \mathrm{C}$ [56]. Note that this result outperforms the power that is needed for electric vehicles. In practice, the grid managers do not permit a delivery of electrical power that exceeds $50 \mathrm{~kW}$ for individuals to recharge their battery, because larger power supply would destabilize the grid. Nevertheless, such a very high powered battery can be used for other applications, like frequency regulations, and solutions for intermittence problems of electricity produced by windmills or photovoltaic plants. It can also equip trains with a regenerative braking system and thus reduce the pollution by highly carcinogenic asbestos particles produced by brakes.

If we look at the advertising of a manufacturer of LTO batteries, GWL POWER LTD ( https://www.ev-power.eu/LTO-Cells/), we can read that LTO batteries have a life cycle of up to 20,000 cycles as compared to only 2000 in standard lithium based batteries. This is true. We can also read that the efficiency of the lithium titanate technology in energy storage solutions allows for a recharge efficiency of up to $98 \%$, much higher than conventional energy storage mechanisms. This is also true, because of the lower voltage of the cells with respect to graphite. With graphite anodes, full charging 
must be avoided for safety reasons and also the aging of the cells is faster at full charge. Then we finally read that LTO offers the highest energy to weight ratio seen yet. This, however, is not true: with respect to a $4 \mathrm{~V}$ cell with carbon anode, the loss of $1.5 \mathrm{~V}$ when using LTO means a loss of energy density raising to $2.5 / 4=62 \%$. This capacity loss cannot be compensated simply by the fact that the state of charge can be raised up to $98 \%$, because on the batteries with carbon anodes, the state of charge is limited to approximately $80 \%$.

We have made elsewhere a critical review of the many active anode elements that are under current investigation in research [57]. We guide the reader to this article, to focus attention of the present work on a critical review on the Li-ion batteries that are already commercial products.

\section{Link between the voltage and the safety}

We have outlined in the former section the paradigm according to which any attempt to increase the energy density by increasing the voltage of the battery results in concomitant decrease of the safety. Robert Huggins has demonstrated that this is due to thermodynamics [58] as the partial pressure of oxygen at equilibrium varies exponentially with the redox potential of the transition- metal oxides versus lithium (see Fig. 7). It is equal to the atmospheric pressure at the voltage of $3 \mathrm{~V}$ and is already larger than $50 \mathrm{~atm}$ pressure for the $4 \mathrm{~V}$ family. Therefore, all the cathodes materials belonging to the lamellar compounds have a propensity to loose oxygen. When oxygen is released, it moves to the counter-electrode, and when it is graphite, the carbon reacts with oxygen to produce $\mathrm{CO}_{2}$. This reaction is exothermic and results in a runaway, in addition to the risk raised by the emission of gas that must be ejected by vents equipping the battery to avoid an explosion.

That is why we have already pointed to the danger that the manufacturers take when they use partial Al substitution of the transition-metal cation of lithium intercalation oxides to increase the cell voltage, simply because they want more energy density.

$\mathrm{LiFePO}_{4}$ escapes this problem for two reasons. First, its redox potential is $3.5 \mathrm{~V}$, lower than that of a lamellar compound. Second, it is a phosphate and not an oxide, i.e., the $\mathrm{PO}_{4}$ group must be considered as a chemical unit, and the oxygen is tightly bound to the $\mathrm{P}$ atoms by covalent bonding. This is one reason that explains the remarkable thermal stability of LFP.

\section{The electrolyte}

The main components of the electrolytes in case the negative electrode is graphite are carbon ates: ethylene carbonate (EC), diethyl carbonate (DEC), ethyl-methyl carbonate (EMC) or dimethylene 
carbonate (DMC), and blend of them, not propylene carbonate (PC) with graphite, since it releases too much gas. We have already pointed to the need to control the formation of the SEI. The first stage takes place before the intercalation of $\mathrm{Li}^{+}$ions into graphite and the SEI formed in this stage is structurally porous, highly resistive, and unstable. This period produces more flammable gaseous products with risk of explosion.

To improve the safety issue, a huge variety of additives have been incorporated in the electrolytes. Therefore, the composition of the electrolytes differs from one manufacturer to the other, and it is always unknown, because the manufacturers are reluctant to give the composition of their product. We have published a review of the different solutions that have been found [59]. The variety of the solutions that are adopted means that none of them is perfect, however. We just list them, here, and guide the reader to Ref. [59] for more details.

Different additives aim to reduce the gas generation and im- prove safety. They are polymerizable additives that are preferably reduced to form an insoluble solid product, which subsequently is covered onto the surface of graphite as a preliminary film to deactivate catalytic activity. In short, those are additives contain- ing carbon-carbon double bonds in their molecules. Their amount, however, should not exceed 2 wt.\% to avoid undesirable side effects. Other additives operate differently, through absorption of their reduced products onto the graphite surface sulfur-based compounds like $\mathrm{SO}_{2} \mathrm{CS}_{2}$ polysulfide, cyclic alkyl sulfites, and aryl sulfites. Another type of additive named reaction-type additive acts by scavenging radical ions, or by combining with the final products of the SEI. Among them, $\mathrm{CO}_{2}$-providers like dimethyl pyrocarbonate favor the formation of the SEI with EC-DEC.

Other additives aim at protection against overcharge, since we have reported in the previous section that overcharge results in self-heating and poses safety problems. The redox shuttle additives are used for this purpose. The oxidized shuttle species diffuse to the negative electrode and are reduced back to the neutral molecule. The oxidation potential of the shuttle molecules must be slightly higher than the normal end-of-charge potential of the positive electrode. This reaction must be reversible; the oxidized and reduced forms must be soluble and mobile. These conditions are satisfied for the anisolefamily compounds in the range $<4 \mathrm{~V}$ so that it works well with the $\mathrm{LiFePO}_{4}$ cathode $[60,61]$. For other electrodes, lithium fluorododecaborates $\left(\mathrm{Li}_{2} \mathrm{~B}_{12} \mathrm{~F}_{\mathrm{x}} \mathrm{H}_{12-\mathrm{x}}\right)$ up to $4.5 \mathrm{~V}$ maximum are used. At contrast with redox shuttle additives, shutdown additives terminate the cell operation definitely. At high potential, the additive molecules polymerize on the surface of the cathode to isolate it from further overcharge. Most of these additives are aromatic compounds. However, these molecules reduce the life of the battery. A 
critical overview on the additives for overcharge protection in LIB has been reported by Belov and Yang who concluded that they are mostly ineffective and have a lot of limitations [62]. As a matter of fact the judgment "ineffective" seems too pessimistic, because they all have some positive effect, but indeed not to the point where the problem is solved.

Fire retardant additives use a chemical radical-scavenging process, which terminates radical chain reactions responsible for the combustion reaction in the gas phase: organic phosphorous compounds. An example is hexamethoxycyclotriphosphazene that is stable up to $5 \mathrm{~V}[63]$. $\mathrm{P}^{3+}$ phosphides have also a fire retardant power, with the advantage that they facilitate the formation of the $\mathrm{SEI}$, and can deactivate $\mathrm{PF}_{5}$ : tris(2,2,2-trifluoroethyl) phosphite (TTFP) is the best example.

The addition of ionic liquids in the electrolyte is also effective to reduce its flammability (see [64] for a review). However, the excessive price of the ionic liquids did not permit their use in the commercial battery yet. In addition, their viscosity is a crucial limitation [65].

\section{The lithium salt}

The choice of $\mathrm{LiPF}_{6}$ in the commercial batteries is due to the fact that it is not only highly conductive, but in addition it creates a passivation layer of $\mathrm{AlF}_{3}$ at the surface of the aluminum electrode, which protects the electrode against the corrosion in the presence of the electrolyte. Unfortunately, there is also safety concern with this lithium salt. It generates isolated LiF that is the important factor to result in unstable SEI. One solution: a boron-based anion receptor to dissolve $\mathrm{LiF}$ is added. The drawback is that it also captures $\mathrm{LiF}$ from $\mathrm{LiPF}_{6}$ to release highly reactive $\mathrm{PF}_{5}$. To avoid this side effect, the aromatic isocyanate is also added, which deactivates the reactivity of electron deficient $\mathrm{PF}_{5}$ with the electrolyte solvents. It also scavenges water and acidic HF from the electrolyte. Weakening the reactivity and acidity of $\mathrm{PF}_{5}$ is possible by adding a weak Lewis base or amide-based compounds.

Another solution consists in the replacement of $\mathrm{LiPF}_{6}$ by another salt. There are, however, not many options. Lithium bis(oxalato) borate ( $\mathrm{LiBOB})$ has the advantage that it protects the aluminum collector from the corrosion with the electrolyte, like does $\mathrm{LiPF}_{6}$. However, it reacts too much with metal oxides (but it works with $\mathrm{LiFePO}_{4}$ ). In addition, it shows a low solubility in solvents with low dielectric constant, lower conductivity, easy hydrolyzability, and difficulty in large-scale synthesis of high-purity, and it is not good at low temperature. LiBF4 $+\gamma$-butyrolactone (GBL) electrolyte has been proposed as a very good combination [66]. Indeed, at first site, this combination looks attractive. $\mathrm{LiBF}_{4}$ 
has a much better thermal stability than $\mathrm{LiPF}_{6}$. It exhibits greater thermal stability [67] and moisture tolerance than $\mathrm{LiPF}_{6}[68]$. GBL is an interesting solvent because of its high flame point, high boiling point, low vapor pressure, and a high conductivity at low temperatures, which increases the safety. $\mathrm{LiBF}_{2}$ has been considered as the only salt that permits full charge-discharge cycles with graphite anodes [69]. This result, however, has been contested, because the Lewis acid-forming salt $\mathrm{LiBF}_{4}$ leads to $\mathrm{LiF}$ formation on the graphite surface during cycling [70, 71]. Finally, Belov et al. [72] determined that the GBL-based electrolyte has a compatible cycle ability with most negative materials. However, the use of the GBL-based electrolytes is limited by its low or non-wet ability with common polyolefin separators, but the use of non-woven separators (see below) should remedy this problem.

\section{The separators}

The separator membrane plays also a major role in battery fires. In particular, electrically conducting dendrites growing inside the separator during charge results in thermal runaway [73]. This element is critical, as its function is to prevent physical contact between the electrodes. It must be porous since it must permit $\mathrm{Li}^{+}$flow. It must be an electrical insulator to prevent any electronic flow that would result in a self-discharge. The requirements, in terms of porosity, chemical stability, wettability of the electrolyte, and mechanical strength, can be found in [74]. In particular, chemical stability and mechanical strength require a thickness of the membrane that is currently about $25 \mu \mathrm{m}$, decreasing to $10 \mu \mathrm{m}$ for the higher density batteries. We have warned that this is the limit today, since smaller thickness would raise a safety risk regarding the mechanical penetration [2]. Therefore, if it is too thin, the separator will be the source of battery fire instead of a protection against it.

Samsung had to recall all of the Galaxy 7 smartphones after battery fires illustrated in Fig. 8. To understand the problems at the origin of the battery fires, three independent societies have investigated the case: Exponent, Underwriters Laboratories, and TÜV Rheinland. The result of the expertise was that two different defects were responsible for the fires, depending on the origin of the batteries issued from two different manufacturers: Samsung SDI and Amperex Technology Ltd. (ATL). For the batteries produced by Samsung SDI, the report mentions that the upper end of the anode was deformed because of a too skimpy packing. The other defect detected on the other batteries coming from ATL report mentions that the problem comes from the soldering of the cathode strap that was to prominent and sharp. The consequence is the dendrite-like expansion of the soldering upon cycling, which drilled the separator, leading to a short circuit and a battery fire. Therefore, these battery fires of the Samsung smartphones illustrate the importance of both manufacturing and having a protecting separator with 
sufficient mechanical strength.

Almost all the separators used in LIBs are based on semi- crystalline polyolefin materials: polyethylene (PE), polypropylene (PP), combined under the form of a PE-PP bilayer [75] or PP-PE-PP trilayer [76, 77]. The PE layer has melting temperature of $130^{\circ} \mathrm{C}$. This is the shutdown temperature, because the melting PE layer is able to fill the pores, which prevents the $\mathrm{Li}^{+}$ions from any motion between the two electrodes. Moreover, The PP film melts only at $165^{\circ} \mathrm{C}$, so that it is still able to maintain the rigidity of the separator at the shutdown temperature, thus preventing a short circuit between the electrodes. In addition, the shutdown temperature is smaller than the temperature of the onset of thermal runaway, so that the separator plays its role to prevent battery fire. In practice, the 35 ${ }^{\circ} \mathrm{C}$ buffer between the PE shutdown and the PP melting is sufficient to insure protection of the Li-ion batteries, unless the overheating due to other deficient elements of the battery is so important that the separator shrinks or melt, in which case, the thermal runaway is inevitable. Such is the case during the nail penetration test and short circuit test when a lamellar compound is used as the cathode element.

For high-power applications that require separators with excellent thermal stability, inorganic composite separators can be used. They are made of oxides of transition metal under the form of ultrathin particles linked by a binder which is usually PVdF or PVdF-HPF. These separators have several advantages: very good thermal stability, they do not shrink at high temperature, they show outstanding wettability with all the electrolytes (which is not the case of PE-based separators). However, they are not mechanically strong enough to fully withstand manufacturing.

An improvement is provided by Separion (a trade mark) separators that combine polymeric non-woven poly(ethyleneterephtalate) (PET) and ceramic nanoparticles [78]. Such a separator has an average pore size of $0.08 \mu \mathrm{m}$, has a thickness of $24 \mu \mathrm{m}$, is thermally stable up to $210{ }^{\circ} \mathrm{C}$, and is an obvious improvement in the safety. For instance, in a nail penetration test on the $8 \mathrm{Ah} \mathrm{Li-ion} \mathrm{pouch}$ cell, the temperature of the cell using the Separion separator does not exceed $58{ }^{\circ} \mathrm{C}$, against $500{ }^{\circ} \mathrm{C}$ for the same cell using PE separators [79]. This illustrates the importance of the separator in the performance and safety of Li-ion batteries.

\section{The battery monitoring system}

From the previous sections, it turns out that the manufacturers rely on the BMS to improve safety. The BMS has mainly two functions. One is to check the balance of the battery. Each battery is composed of many cells. As we have seen, a cell can burn. By chain reaction, however, a battery can explode. To avoid this dramatic issue, the BMS control the state of each cell, by measuring the voltage of each of them for instance, and will stop the current if the voltage of one of them differs from the 
others by more than few \%. This small tolerance is usually sufficient to prevent the chain reaction between the cells. Therefore, the BMS is efficient to avoid explosion of the batteries, but obviously fails to prevent the thermal runaway in view of the battery fires that we have reported. The second function of the BMS is the estimation of the state-of- health (SOH). The cycle life of Li-ion batteries with graphite anodes is well documented, and the loss of capacity follows a power law relation with time $[80,81]$, mainly due to the thickening of the SEI. The life of a Li-ion battery with LTO is much longer, and the capacity loss is quite different since no significant SEI is formed. The on-line diagnosis and SOH estimation for LTO-based anode Li-ion batteries has been made in Ref. [53], using the incremental capacity curve, i.e., $d Q / d V=f(V)$ and the differential voltage curve, i.e., $d V / d Q=f(Q)$. As a conclusion, the experience shows that the BMS fails to prevent any thermal runaway, but it avoids explosion and is efficient to determine the $\mathrm{SOH}$.

\section{Applications}

\section{Application to electric vehicles}

The introduction in almost all the papers related to LIBs mention their application to electric vehicles, which reduce the pollution and the emission of greenhouse gas. This statement is justified, but only partly, however. To determine the real impact of the electric vehicles, we can refer to a report (in French) of the "Agence de l'Environment et de la Maîtrise de l'Energie (ADEME)" (http://www.ademe.fr/sites/default/files/assets/documents/90511_acv-comparative-ve-vt-rapport.pdf).

The cost in greenhouse gas is much larger to fabricate an electric car than a traditional car. The reasons is that the fabrication of the battery emits greenhouse gas, the extraction of copper for the current collector and wiring, and of the transition metals entering the composition of the cathode, and of the lithium from the mines also emits a lot of greenhouse gas. Then these materials are transported to another place where the battery is made. Finally, the batteries are transported to the place where the cars are made. All these transportations emit greenhouse gas. On the other hand, the consumption of electricity instead of gas is in favor of the electric car, more or less depending on the process used to produce the electricity. As a result, according to the ADEME, in France where the electricity is generated mainly by nuclear plants, the environmental pertinence of the electric car concerning greenhouse gas is favorable to the electric car after 80,000 km. However, in Germany where the electricity is generated mainly by thermic plants, the electric car is never pertinent even if the battery has a life sufficient to keep the car running $180,000 \mathrm{~km}$, after the same report. A cynic might argue that the pollution associated to the fabrication is located mainly in remote areas where the mines are located, i.e., where the density of population is small. On the other hand, it is beneficial to people living 
in regions where the population is dense since the electric car is used mainly in metropoles, so that the net result is positive for people. But at the scale of the planet the net environmental effect and consequences on the climate do not depend on this geographical distribution.

There is, however, an advantage of the electric vehicle, irrespective of the place where it is used: the production of fine particles. In the case of a diesel car, they are emitted during driving. For gas and electric cars, they are mainly generated during braking. However, an experienced driver of an electric car will avoid to use brakes as much as possible; instead, he/she will use the kinetic energy to charge the battery, thus reducing the generation of such particles that are dangerous for the health. This effect, however, has not been considered in the ADEME report and has not been quantified to our knowledge.

In the same spirit, another advantage of the regenerative brake technology above mentioned is the reduction of the consumption of electricity. This is not a big advantage in case of fully electric cars if they are mainly used to travel though the countryside. This is, however, an important advantage in case of hybrid and HEV cars, or electric Bolloré cars in France, which are intended to travel in towns where traffic jams impose repeated acceleration and slowdown. This effect has not been well taken into account in the ADEME report that focuses on fully electric vehicles with typical 200-300 km driving range and thus intended to more extensive use outside towns. The use of electric cars restricted in metropole areas is clearly "cleaner" than the use in long-range driving, and the ADEME report in this case is too pessimistic. To the contrary, it is too optimistic if the aim of the car makers is to increase the driving range of the electric vehicles to replace the other cars, because it implies increasing the size of the Li-ion batteries, and thus the carbon emission of the electric car needed to make it before use.

Therefore, the reasons why some countries subsidize electric cars, but not HEV or hybrid cars (case in France for instance) are presumably political in nature (impact on the budget for instance), but are not based on scientific grounds. Indeed, the countries have different politics. In Germany, both the EV's and the HEV are subsidized (4000 and $3000 €$, respectively). In the USA, those are the car companies that are subsidized.

Finally, the ADEME report predicts a reduction of green-gas emission associated to the electric car by $20 \%$ if LFP is used as the cathode instead of the lamellar compounds. This is good news for Asia and in particular in China where this cathode is developing fast, but Europe for instance is more tempted to increase the energy density, even if the Bolloré car in France uses the LFP (with a lithium metal-polymer technology). In any case, the claim often found in the literature according to which the electric car is a solution of zero-emission of greenhouse gas transportation is misleading. With the present technology, the electric car reduces the emission of greenhouse gas provided that the electricity 
is supplied by processes that do not emit large amounts of carbon and provided that the use of the car is limited to town areas to avoid the use of large batteries.

\section{Application to smart grid}

Li-ion batteries can also be used to buffer the intermittence problems associated to windmill and solar plants. To store amount of energies higher than $100 \mathrm{MWh}$, the methods that are used are pumpedstorage hydroelectricity (PSH), or compressed air energy storage (CAES). The electrochemical batteries are currently used only for energy storage at a smaller scale. In this framework, Li-ion batteries have to compete with other members of this family. We have published elsewhere a comparison between them in terms of performance and price [82]. In particular, all the references of the numerical performance values reported in this section and the sources of the data are reported in [82]. Here, we only extract from this prior work the results for comparison with Li-ion batteries.

For on-grid storage feature, lead batteries have some advantages such as (i) robustness, (i) low self-discharge (0.1-0.2\% per day, and (iii) do not require sophisticated management systems. The main advantage, with respect to Li-ion batteries in particular, is the low cost per kilowatt-hour (typical about 120 to $200 €$ ) to install and low cost per kilowatt-hour electricity throughput (typical range 0.1 to $0.15 €$ per kWh turn over for battery only). Their disadvantages are as follows: (i) low energy and power densities (30 $\mathrm{Wh} \mathrm{kg}^{-1}$ and $180 \mathrm{~W} \mathrm{~kg}^{-1}$, respectively), (ii) low cycle life (1800 cycles), (iii) high sensitivity to temperature as a departure by 2 degrees from the nominal temperature $\left(25^{\circ} \mathrm{C}\right)$ reduces the life by a factor 2 . High operating temperatures (up to $45^{\circ} \mathrm{C}$ ) can improve the battery performance in terms of higher capacity, but reduce the life time of the system; (iv) the charge must be done at low rate and (v) sulfation can lead to premature failure of the battery.

The main problem with the sodium-sulfur battery is safety, since the sodium is highly corrosive and burns spontaneously in contact with air and moisture. A variant on the high-temperature sodiummetal battery chemistries is the sodium-nickel-chloride Durathon Battery technology that is more promising, with improved characteristics: (i) calendar life $>10$ years in stationary float applications, cycle life 4500 cycles at $80 \%$ depth of discharge (DOD), (ii) operating temperature range -30 to +60 ${ }^{\circ} \mathrm{C}$ without power reduction, (iii) energy density $120 \mathrm{Wh} \mathrm{kg}^{-1}\left(140 \mathrm{Wh} \mathrm{L}^{-1}\right)$ at battery level, (iv) energy efficiency $92 \%$ at $\mathrm{C} / 4$ rate, and (v) power rate up to the MW size and 3 to $6 \mathrm{~h}$ energy are under test. However, with the new Li-ion technology that allows for cycling lives larger than 30,000 cycles, it remains to be seen how the markets will decide on Durathon.

After lead-based batteries, the second electrochemical energy storage used is nickel-based batteries, and among them nickel-metal hydride $(\mathrm{NiMH})$ is preferred. It can perform over extended 
periods of time in a wide operating range of -30 to $+65^{\circ} \mathrm{C}$, significantly reducing the complexity and cost of thermal management systems required for a utility-scale energy storage installation. Note for the same reason, the simple (not plug-in) hybrid electric cars are equipped with such a battery. With the improvement of the safety of $\mathrm{LiFePO}_{4}$ positive electrodes of $\mathrm{Li}$-ion batteries, however, and the possibility to extend the operating temperature range of the electrolytes when the counter-electrode is LTO [83], the advantage of NiMH is reduced to the cost, and we see below the cost of the Li-ion batteries decreases very fast.

Three flow batteries can be found on the market. The vanadium flow battery has the following characteristics: (i) energy rating: mostly in the range of the MWh, (ii) power rating of 0.2-10 MW, (iii) cycling capability of 10,000, (iv) life of $15-20$ years, and (v) energy efficiency: circa $75 \%$. The main problem is that vanadium and the membranes are very expensive. It is even recommended to replace the membrane every 5years [84], which enhances even more the cost of the kilowatt-hour. The world's largest vanadium flow battery on line in 2012 is the $600 \mathrm{~kW} / 3.6 \mathrm{MWh}$ VRB ${ }^{\circledR}$ Energy Storage System used to expand onsite power generation at an agricultural processing facility in California. The second flow battery is the zinc-bromine flow battery available in sizes of $1 \mathrm{MW} / 3 \mathrm{MWh}$ for utility-scale applications. This system has a high cell voltage, good reversibility, and expectations of low material costs, so that the performance is improved with respect to the vanadium flow battery as follows: (i) energy rating of 0.1-4 MWh, (ii) power rating of 0.2-1 MW, (iii) specific energy of 70-90 $\mathrm{Wh} \mathrm{kg}^{-1}$, and (iv) specific power of $45 \mathrm{~W} \mathrm{~kg}^{-1}$. The total system cost is circa $600 \$$ per kilowatt-hour. However, the toxicity of $\mathrm{Br}_{2}$ and the highly complexing/corroding character of concentrated $\mathrm{HBr}$ are limitations. Material corrosion that limits the life and dendrite formation that limits the power density are also issues that limited the development. The third system is the bromine/polysulphide flow battery. This system is not as attractive as the two other ones, because it is prone to crossover and mixing of the electrolytes, which can lead to precipitation of sulfur species and the formation of $\mathrm{H}_{2} \mathrm{~S}_{\text {and }} \mathrm{Br}_{2}$. Then a tank failure would expel toxic bromine gas. In addition, the regular maintenance is heavy, as it includes a bi-weekly removal of sodium sulfate crystal by-products. Other maintenance tasks including spent absorbent and replenishment and maintenance of the electrolytic solution must be done quarterly.

In this context, Li-ion batteries are winning a part of the market. Many stationary Li-ion batteries are now operated worldwide in grid-connected installations. Systems in association with distributed renewable generators from a few $\mathrm{kW}$ to several $\mathrm{MW}$, as well as for grid support with voltages up to $6000 \mathrm{~V}$ have been designed and successfully tested. AES Energy Storage (http://www.aesenergystorage.com/) has installed a 32-MW lithium-ion storage system to regulate the 
100-MW Laurel Mountain Wind Farm in West Virginia. The largest battery-based energy storage today is made of two energy storage arrays totaling 37.5 MW provided by the AES Corporation (NYSE: AES) under contract with San Diego Gas and Electric (SDG\&E) operating by the end of January 2017. The SDG\&E arrays using Advancion ${ }^{\circledR}$ technology are able to provide $37.5 \mathrm{MW}$ of power for four continuous hours (i.e., an energy $140 \mathrm{MWh}$ ) and serve as a $75 \mathrm{MW}$ of flexible resource to the grid. Note the batteries are provided by Samsung SDI, hopefully with a technology for the separator different from the one that equipped the "Galaxy 7" smartphones. Indeed, in such devices where the arrays are on the ground, one is limited neither by the weight nor the volume nor the number of cells, so that high performances can be obtained safely more easily than in the smartphones or electric cars where the limitations in volume are stringent. New opportunities are opened by the progress in the technology of Li-ion batteries with the development of LFP and LTO electrodes, and the progress in the technology of graphene-based super-capacitors. Integrated supercapacitor/Li-ion battery back-up are expected to make significant inroads in the near future, by combining high energy and high power. This combination is very well suited to maintain voltage and frequency quality during instabilities of base load generating sources. Actually, the grid applications might be the main source of development for Li-ion batteries. The Li-ion batteries have many advantages with respect to the other technologies cited above. Their energy density is large, the cycling life depends on the choice of the electrodes, but it can be larger than 30,000 cycles in the case of LFP//LTO. With this particular choice, the energy density is still larger although comparable to $\mathrm{NiMH}$, but the power density is orders of magnitude larger, and different choices of electrolytes allow the extension of the operating temperature range to be the same as that of NiMH. If the energy density is privileged, then graphite anode is inevitable for the moment, even if the advance in the re- search on new anode materials is promising [2] for the near future. With the graphite anodes, Li-ion batteries rank number one for the energy density. The only parameter that slowed the development of Li-ion batteries is the price. But this is changing fast. Between January 2015 and June 2016, Stem recorded a fall of the Li-ion battery price by $70 \%$ in the last 18 months (https://www.greentechmedia.com/articles/read/stem-cto-weve-seen-battery-prices-fall-70-in-the-last 18-months) and predicts a similar drop in the next 18 months or 2 years. The reason invoked to explain this sharp drop in prices is the expansion of worldwide production capacity, and since much of the new capacity was designed for electric vehicle demand that never materialized, stationary storage vendors are getting a better deal.

\section{Conclusion}

The main difficulty met to develop the Li-ion technology in transportation in portable 
applications is the safety issue associated to the risk of thermal runaway. The problem is that in transport either in planes or in electric cars, one needs the largest energy density possible. However, thermodynamics imply that larger voltage of the cells result in an increase in the risk of battery fire. Therefore, the safety relies today on the BMS. As we have seen, however, through different examples, the BMS is not sufficient to guarantee the safety. Moreover, more the BMS is sophisticated, more it is expensive. Therefore, a compromise has to be found, which limits and will limit the use of this technology more or less, depending on the risk that the manufacturers and the users will be ready to take and also on the limits in the power that the electricity suppliers are able to deliver to individuals without destabilizing the grid. For instance, Samsung SDI made recently an advertisement at the North American International Auto Show in Detroit in January 2017 to let people (at least the competitors) know that it would commercialize batteries offering a range of $600 \mathrm{~km}$ with $80 \%$ charge within 20 min by 2021. To be different from histrionics, however, such an advertising should always be associated to a claim on what would be the true progress and advance in technology that would permit the use of such batteries safely, and which progress in the grid management is expected to allow individuals to have at their disposal the power needed for this purpose.

The safety problem is less stringent for grid applications. As an example, the consequence of a fire in a plane in the middle of an ocean has not the same consequence as a fire of a battery on the ground. Also, the weight and volume occupied by the battery implemented on the ground for grid applications are parameters that are less important than in the case of portable use. Indeed the future of the Li-ion batteries for grid applications looks bright. Tesla in the USA, Panasonic, LG Chem, and Samsung SDI in Asia are developing a huge production of Li-ion batteries, resulting in drastic decrease of their price, which in turn justifies the building of new utilities for stationary applications. 


\section{References}

[1]. Nagaura, T.; Tozawa, K. Lithium ion rechargeable battery. Prog. Batter. Sol. Cells 1990, 9, 209-211.

[2]. C. M. Julien, A. Mauger, A. Vijh, K. Zaghib, Lithium Batteries: Science and Technology. Springer 2015.

[3]. S.F. Lux, I.T. Lucas, E. Pollak, S. Passerini, M. Winter, R. Kostecki, Electrochem. Commun. 14 (2012) 47.

[4]. T. Ohzuku, A. Ueda, M. Nagayama, Y. Iwakashi, H. Komori, Electrochim. Acta 38 (1993) 1159.

[5]. J. R. Dahn, E. W. Fuller, M. Obrovak, U. Von Sacken, Solid Stat. Ionics 69 (1994) 265.

[6]. Z. Zhang, D. Fouchard, J. R. Rea, J. Power Sources 70 (1998) 16.

[7]. V. Bianchi, D. Caurant, N. Baffier, C. Belhomme, E. Chappel, G. Chouteau, S. Bach, J. P. PereiraRamos, A. Sulpice, P. Wilmann, Solid State Ionics 140 (2001) 1.

[8]. C. M. Julien, C. Letranchant, S. Rangan, M. Lemal, S. Ziolkiewicz, S. Castro-garcia, L. El-Farh, M. Bankaddour, Mter. Sci. Eng. B 76 (2000) 145.

[9]. R. V. Chebiam, F. Prado, A. Manthiram, Chem. Mater 13. (2001) 2951.

[10]. C. V. Ramana, K. Zaghib, C. M. Julien, Chem. Mater. 18 (2006) 1397.

[11]. K. C. Mahesh, G. S. Suresh, A. J. Bhattacharyya, T. V. Venkatesha, J. Electrochem. Soc. 159 (2012) A571.

[12]. B. V. R. Choudari, G. V. Subba Rao, and S. Y. Chow, Solid State Ionics, 140 (2001) 55.

[13]. J. Weaving, F. Coowar, D. Teagle, J. Cullen, V. Dass, P. Bindin, R. Green, W. Macklin, J. Power Sources 97 (2001) 733.

[14]. K. Zaghib, J. Dubé, A. Dallaire, K. Galoustov, A. Guerfi, M. Ramanathan, A. Benmayza, J. Prakash, A. Mauger, C.M. Julien, J. Power Sources 219 (2012) 36

[15]. Z. Liu, A. Yu, J. Y. Lee, J. Power Sources 81-82 (1999) 416.

[16]. Z. Lu, D.D. Mac Neil, J. R. Dahn, Electrochem. Solid Stat. Lett. 4 (2001) A200.

[17]. D.D. Mac Neil, Z. Lu, J. R. Dahn, J. Electrochem. Soc. 149 (2002) A1332.

[18]. A. Mauger, F. Gendron, C. M. Julien, J. Alloys Compds 520 (2012) 42

[19] D. Aurbach, K. Gamolsky, B. Markowsky, G. Salitra, G. Y. Gofer, U. Heider, R. Oesten, M. Schmidt, J. Electrochem. Soc. 147 (2000) 1322.

[20] A. Mauger, C. M. Julien, Ionics 20 (2014) 751.

[21]. E. H. Lee, J. H. Park, J. H. Cho, S. J. Cho, D. W. Kim, H. Dan, Y. Kang, S. Y. Lee, J. Power 
Sources 244 (2013) 389

[22]. T. Baumhöfer, M. Brühl, S. Rothgang, D.U. Sauer, J. Power Sources 247 (2014) 332.

[23]. M. M. Tackeray, Y. Shao-Horn, A. J. Kahayan, K. D. Kepler, E. Skinner, J. T. Vaughey, S. A. Hackney, Electrochem. Solid Stat. Lett. 1 (1998) 7.

[24]. D. H. Jang, J. Y. Shin, S. M. Oh, J. Elecgrochem. Soc. 143 (1996) 2204.

[25]. M. Dubarry, C. Truchot, B.Y. Liaw, K. Gering, S. Sazhin, D. Jamison, C. Michelbacher, J. Power Sources 196 (2011) 10336.

[26]. G. Ceder, M. Chiang, D. R. Sado, M. K. Aydinol, Y.-I. Jang, B. Huang, Nature 392 (1998) 694.

[27]. T. Ohzuku, T. Yanagawa, M. Kouguchi, A. Ueda, J. Power Sources 68 (1997) 131.

[28]. Japanese Patent Application Laid-open (KOKAI) No. 2004-127694.

[29]. K. Zaghib, M. Trudeau A. Guerfi, J.Trottier, A. Mauger, R. Veillette, C. M. Julien, J. Power sources 204 (2012) 177.

[30]. D. Liu, J. Trottier, P. Charest, J. Fréchette, A. Guerfi, A. Mauger, C. M. Julien, K. Zaghib, J. Power Sources 204 (2012) 127.

[31]. F. Xu, H. He, YD Liu, C. Dun, Y. Ren, Q. Liu, M.-X. Wang, J. Xie J. Electrochem. Soc. 159(5) (2012) A678.

[32]. F. Xu, H. He, C. Dun, YD Liu, M.-X. Wang, Q. Liu, Y. Ren, J. Xie, ECS Trans. 41(39) (2012) 1. [33]. A. Ait-Salah, A. Mauger, C. M. Julien, F. Gendron, Mater. Sci. Eng. B 129 (2006) 232.

[34]. K. Zaghib, A. Mauger, J. B. Goodenough, F. Gendron, C. M. Julien, in: Garche J (ed)

Encyclopedia of electrochemical power sources, five-volume set. Elsevier, Amsterdam.

[35]. C. Kim, J. Park, K. Lee, J. Power Sources 163 (2006) 144; Y. Liu, C. Kao, X. Xu, J. Appl.

Electrochem. 40 (2010) 419.

[36]. Liu Y, Kao C, Xu X (2010) J Appl Electrochem 40:419-425.

[37]. Zaghib, K., A. Mauger, C. M. Julien, J. Solid State Electrochem. 16 (2012) 835.

[38]. S. Y. Chung, J. T. Bloking, Y. M. Chiang, Nat. Mater. 1 (2002) 123.

[39]. K. Zaghib, A. Mauger, J. B. Goodenough, F. Gendron, C. M. Julien, Chem. Mater. 19 (2007) 3740 .

[40]. M. S. Islam, D. J. Driscoll, C. A. Fischer, P. R. Slater, Chem. Mater. 17 (2007) 5085.

[41]. C.A.J. Fisher, V.M.H. Prieto, M. S. Islam, Chem. Mater. 20 (2008) 5907.

[42]. M. Wagenmaker, B. L. Ellis, D. Lützenkirchen-Hecht, F. M. Mulder, L. F. Nazar, Chemistry of Materials 20(20) (2008) 6313.

[43]. N. Ravet, A. Abouimrane, M. Armand, Nat. Mater. 2 (2003) 702.

[44]. P. S. Herle, B. Ellis, N. Coombs, L. F. Nazar, Nat. Mater. 3 (2004) 147. 
[45]. B. Kang, G. Ceder, Nature 458 (2009) 190.

[46]. K. Zaghib, J. B. Goodenough, A. Mauger, C. M. Julien, J. Power Sources 194 (2009) 1021.

[47]. A. Herold Bull. Soc. Chim. (France) 187 (1955) 999.

[48]. R. Juza, V. Wehle, Nature 52 (1965) 560.

[49]. J. O. Besenhard, G. Eichinger, J. Electroanal. Chem. 68 (1976) 1-18.

[50]. G. Eichinger, J. O. Besenhard, J. Electroanal.72 (1976) 1-31.

[51]. M. Armand, M. Duclot, French patent No. 78 32976, November 22, 1978

[52]. F. Joho, P. Novak, M. E. Spahr, J. Electrochem. Soc. 149(8) (2002) A1020.

[53]. X. Han, M. Ouyang, L. Lu, J. Li, Energies 7 (2014) 4895.

[54]. S. F. Lux, J. Chevalier, Y. T. Lucas, Kostecki, ECS Electrochem. Lett. 2(12) (2013) A121.

[55]. K. Zaghib, M. Dontigny, A. Guerfi, P. Charest, I. Rodrigues, A. Mauger, C. M. Julien, J. Power Sources 196 (2011) 3949.

[56]. K. Zaghib, M. Dontigny, A. Guerfi, J. Trottier, J. Hamel-Paquet, V. Gariepy, K. Galoutov, P. Hovington, A. Mauger, H. Groult, C. M. Julien, J. Power Sources 216 (2012) 192.

[57]. A. Mauger, C. M. Julien, Nanomaterials 5 (2015) 2279.

[58]. R. Huggins, J. Electrochem. Soc. 160(5) (2013) A3001.

[59]. K. Zaghib, J. Dubé, A. Dallaire, K. Galoustov, A. Guerfi, M. Ramanathan, A. Benmayza, J.

Prakash, A. Mauger, C.M. Julien, Chapitre 19 in «Lithium-Ion Batteries: Advances and Applications » Elsevier, copyright 2014.

[60]. J. R. Dahn, J. Jiang, M. D. Fleischauer, C. Buhrmester, L. J. Krause, J. Electrochem. Soc. 152 (2005) A1283, X. M. Feng, X. P. Ai, H. X. Yang, J. Appl. Electrochem. 34 (2004) 1199.

[61]. Feng XM, Ai XP, Yang HX (2004) J Appl Electrochem 34:1199-1203

[62]. D. Belov, M.-H. Yang, ECS Trans 6 (2007) 29.

[63]. C. W. Lee, R. Venkatachalapathy, J. Prakash, Electrochem. Solid-State Lett. 3(2) (2000) 63.

[64]. H. Srour, L. Chancelier, E. Bolimowska, et al. J Appl; Electrochem; 46 (2016) 149.

[65]. A. Lewandowski, A. Swiderska-Mocek, J. Power Sources 194 (2009) 601.

[66]. K. Zaghib, P. Charest, A. Guerfi, J. Shim, M. Perrier, K. Striebel, J. Power Sources 146 (2005) 380.

[67]. S. Zhang, K. Xu, T. Jow, J. Solid State Electrochem. 7 (3) (2003) 147.

[68]. S. Zhang, K. Xu, T. Jow, J. Electrochem. Soc. 149(5) A586.

[69]. N. Takami, M. Sekino, T. Ohsaki, M. Kanda, M. yamamoto, J. Power Sources 97-98 (2001) 677.

[70]A. M. Andersson, A. Henningsson, H. Siegbahn, U. Jansson, K. Edström, J. Power Sources 119121 (2003) 522. 
[71]. M. Andersson, K. Edström, J. Electrochem. Soc.148 (2001) A1100.

[72]. D. Belov, D. T. Shieh, J Solid State Electrochem 16 (2012) 603.

[73]. D. Belov, M. H. Yang, Solid State Ionics 179 (2008) 1816.

[74]. S. S. Zhang, J. Power Sources 164 (2007) 351.

[75]. W. C. Yu, M. W. Geiger, US Patent5,565,281.

[76]. R. W. Callahan, R. W. Call, K. J. Harleson, T. H. Yu, US Patent 6,602,593.

[77]. M. Kinouchi, T. Akazawa, T. Oe, R. Kogure, K. Kawabata, Y. Nakakita, US Ptant 6,627,346

[78]. V. Hennige, C. Hying, G. Horpel, P. Novak, J. Vetter (2006) US Patent 20,060,078,791.

[79]. S. Augustin, V. D. Hennige, G. Horpel, C. Hying, P. Haug, A. Perner, M. Pompetzki, T. Wohrle, C.

Wurm, D. Ilic, Meeting Abstract Electrochem. Soc. 502 Abstract 84.

[80]. I. Bloom, B.W. Cole, J.J. Sohn, S.A. Jones, E.G. Polzin, V.S. Battaglia, G.L. Henriksen, C.

Motloch, R. Richardson, T. Unkelhaeuser, et al. J. Power Sources 101 (2001) 238.

[81]. J. Wang, JP. Liu, J. Hicks-Garner, E. Sherman, S. Soukiazian, M. Verbrugge, H. Tataria, J.

Musser, P. Finamore, J. Power Sources 196 (2011) 3942.

[82]. Zaghib K, Mauger A, Julien CM (2015) In: Franco AA (ed) Rechargeable lithium batteries,

Woodhead Publ Ser in Energy, vol 81. Elsevier, Amsterdam

[83]. Zaghib K, Dontigny M, Guerfi A, Perret P, Ramanathan M, Prakash J, Mauger A, Julien CM (2014b) J Power Sources 248:1050-1057

[84]. Rydh CJ (1999) J Power Sources 80:21 
Table 1

\begin{tabular}{|c|c|c|c|c|}
\hline $\begin{array}{c}\text { Acrony } \\
\mathrm{m}\end{array}$ & Cathode & Anode & $\begin{array}{c}\text { Cell voltage } \\
(\mathrm{V})\end{array}$ & $\begin{array}{c}\text { Energy density } \\
\left(\mathrm{Wh} \mathrm{kg}^{-1}\right)\end{array}$ \\
\hline $\mathrm{LCO}$ & $\mathrm{LiCoO}_{2}$ & graphite & $3.7-3.9$ & 140 \\
$\mathrm{LNO}$ & $\mathrm{LiNiO}_{2}$ & graphite & 3.6 & 150 \\
$\mathrm{NCA}$ & $\mathrm{LiNi}_{0.8} \mathrm{Co}_{0.15} \mathrm{Al}_{0.05} \mathrm{O}$ & graphite & 3.65 & 130 \\
$\mathrm{NMC}$ & 2 & graphite & $3.8-4.0$ & 170 \\
$\mathrm{LMO}$ & $\mathrm{LiNi}_{\mathrm{x}} \mathrm{Mn}_{\mathrm{y}} \mathrm{Co}_{1-\mathrm{x}-\mathrm{y}} \mathrm{O}_{2}$ & graphite & 4.0 & 120 \\
$\mathrm{LNM}$ & $\mathrm{LiMn}_{2} \mathrm{O}_{4}$ & graphite & 4.8 & 140 \\
$\mathrm{LFP}$ & $\mathrm{LiNi}_{1 / 2} \mathrm{Mn}_{3 / 2} \mathrm{O}_{4}$ & $\mathrm{Li}_{4} \mathrm{Ti}_{5} \mathrm{O}_{12}$ & $2.3-2.5$ & 100 \\
& $\mathrm{LiFePO}_{4}$ & & & \\
\hline
\end{tabular}




\section{Table 1: table 2.7 p52 de notre livre}

\section{Figure cations}

Fig. 1. Image of a PC erupting in fire in July 2006, which forced Dell to recall more than 4 millions of Sony batteries.

Fig. 2. DSC spectra of over charged layered, spinel and olivine cathodes with traces of $1.2 \mathrm{~mol} \mathrm{~L}^{-1}$ $\mathrm{LiPF}_{6}$ in EC-EMC (3:7) electrolyte at $10^{\circ} \mathrm{C} \mathrm{min}^{-1}[14]$.

Fig. 3. Example of thermal runaway of the battery of a Tesla car (this one was at Oslo in January 2016).

Fig. 4. Cell temperature measured at side, top and base of the heater (the curves are superposed) and insitu open-circuit potential chronological record of different 18,650 cells subjected to ARC test [14].

Fig. 5. Result of thermal runaway of a Yuasa battery on the Boeing 757 Dreamliner.

Fig. 6. Crystal structure of $\mathrm{LiFePO}_{4}$. Fe atoms are in brown color, oxygen in blue, and lithium in green on the web version.

Fig. 7. Relation between the voltage versus lithium and the oxygen pressure at equilibrium as a for transition metal oxides [60].

Fig. 8. Result of the battery fire of a "Galaxy 7" smartphone 


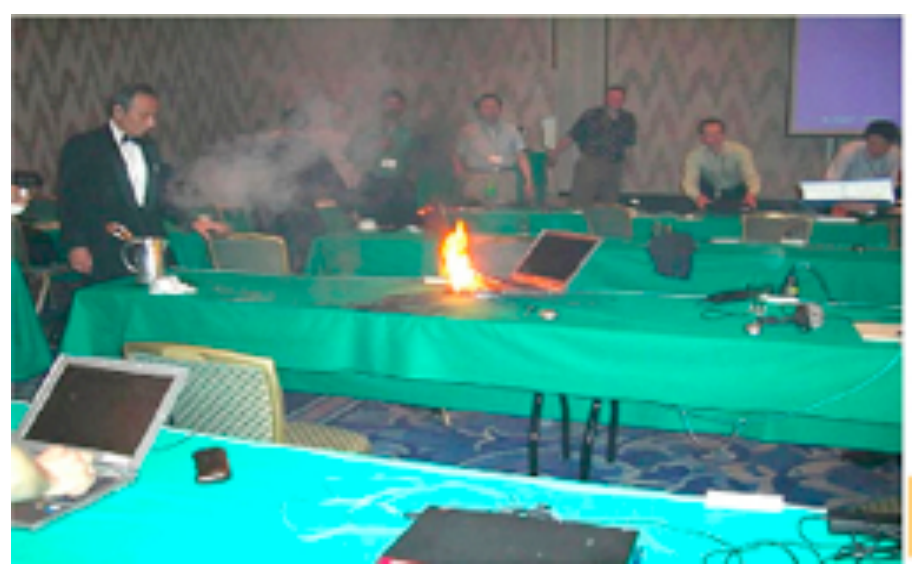

Figure 1

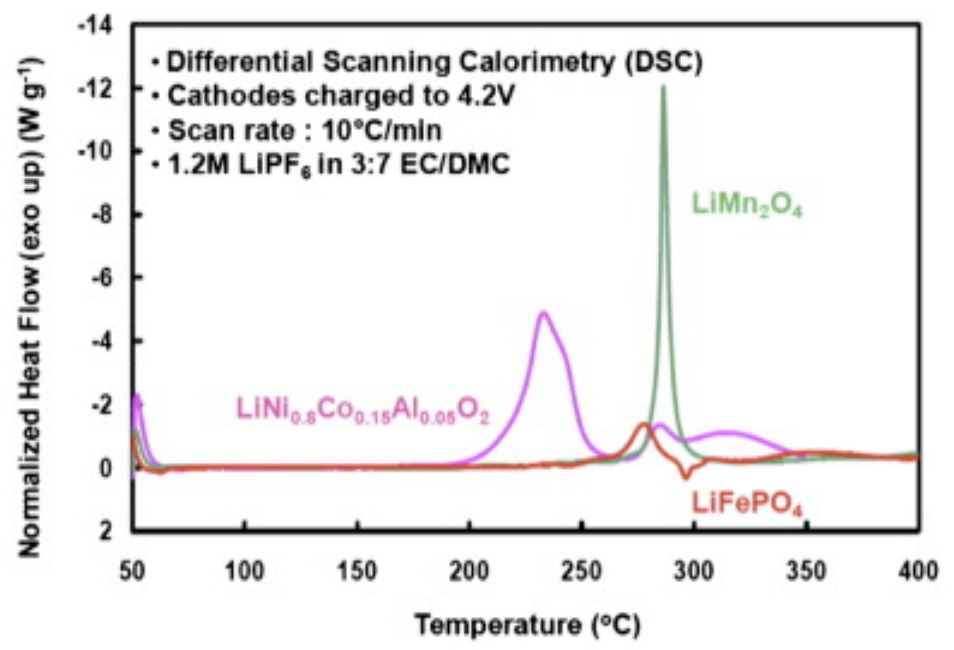

Figure 2 


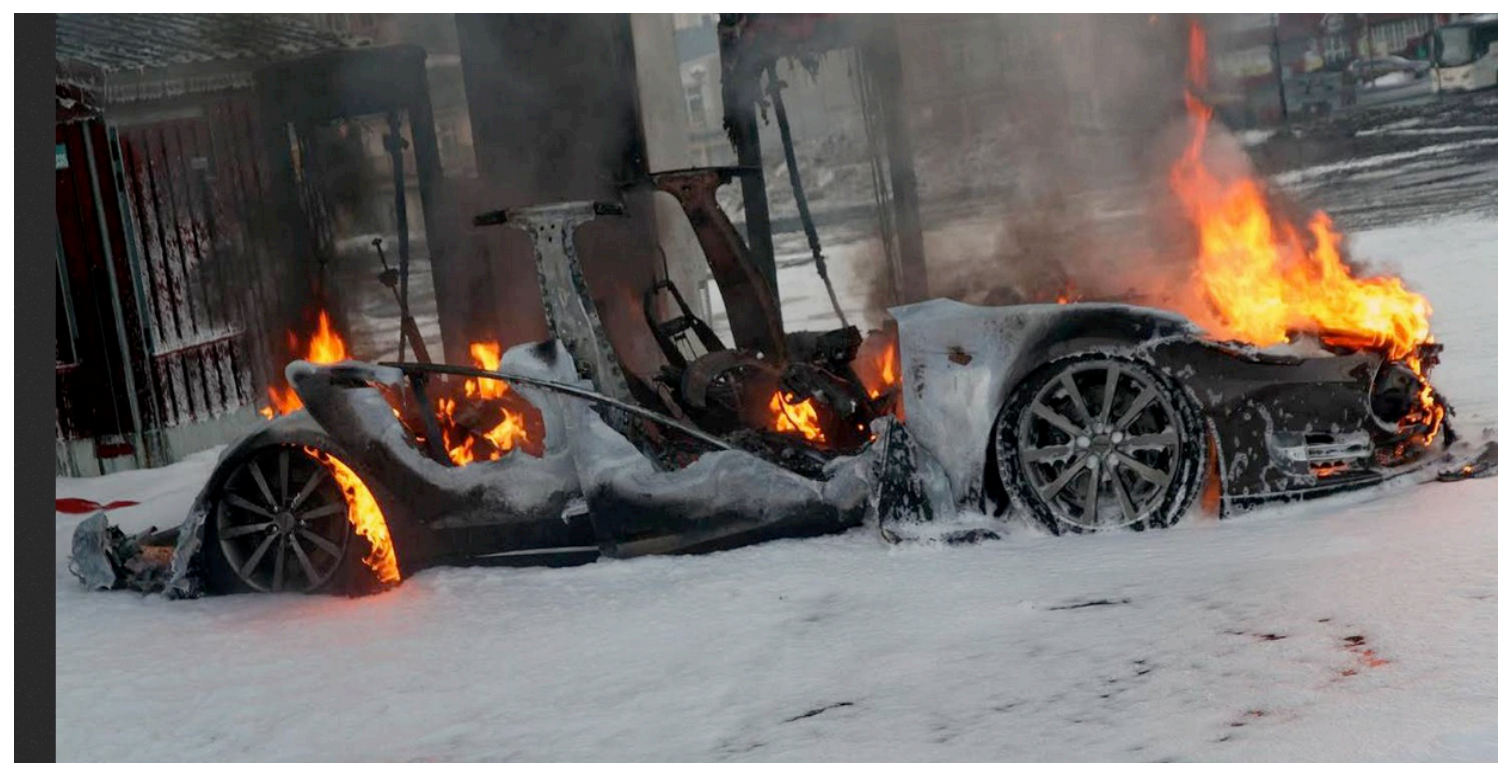

Figure 3 


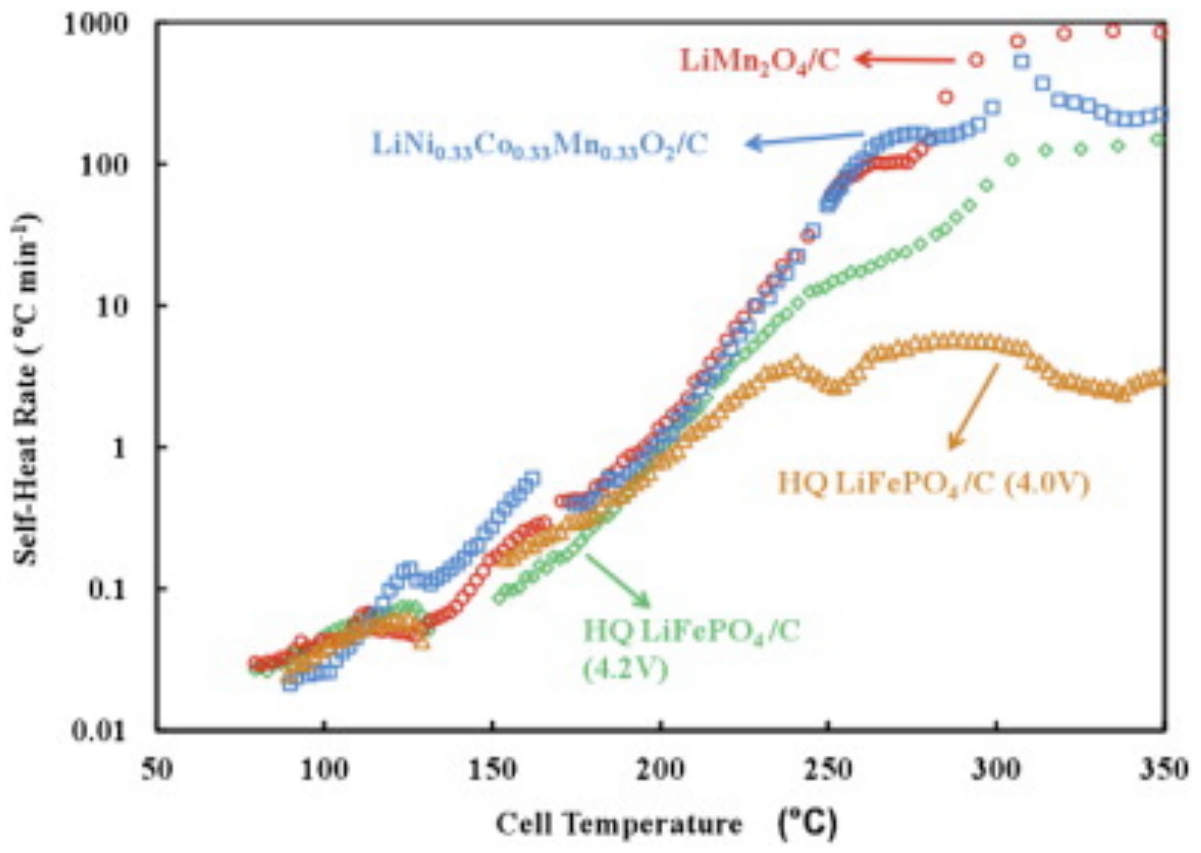

Figure 4 


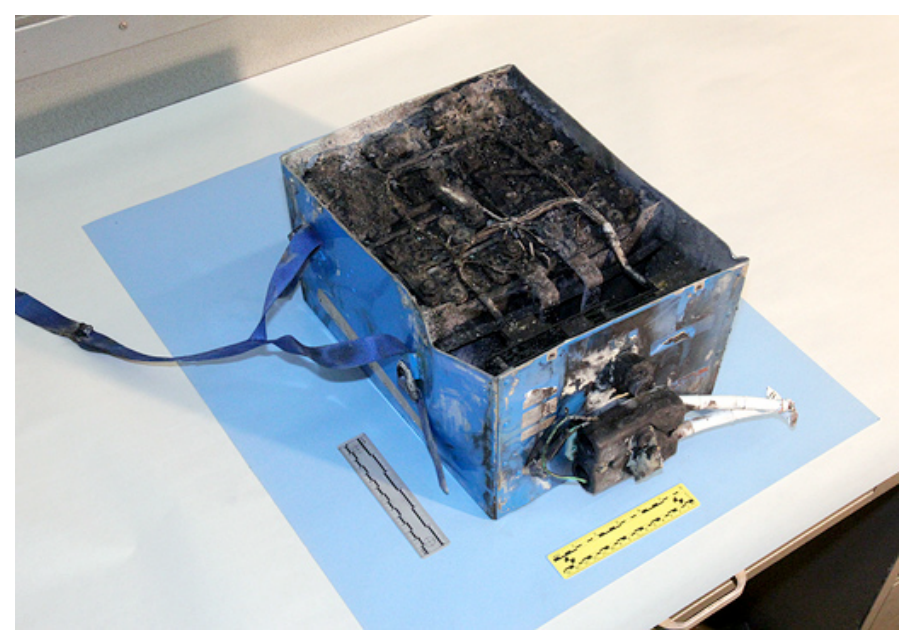

Fig. 5

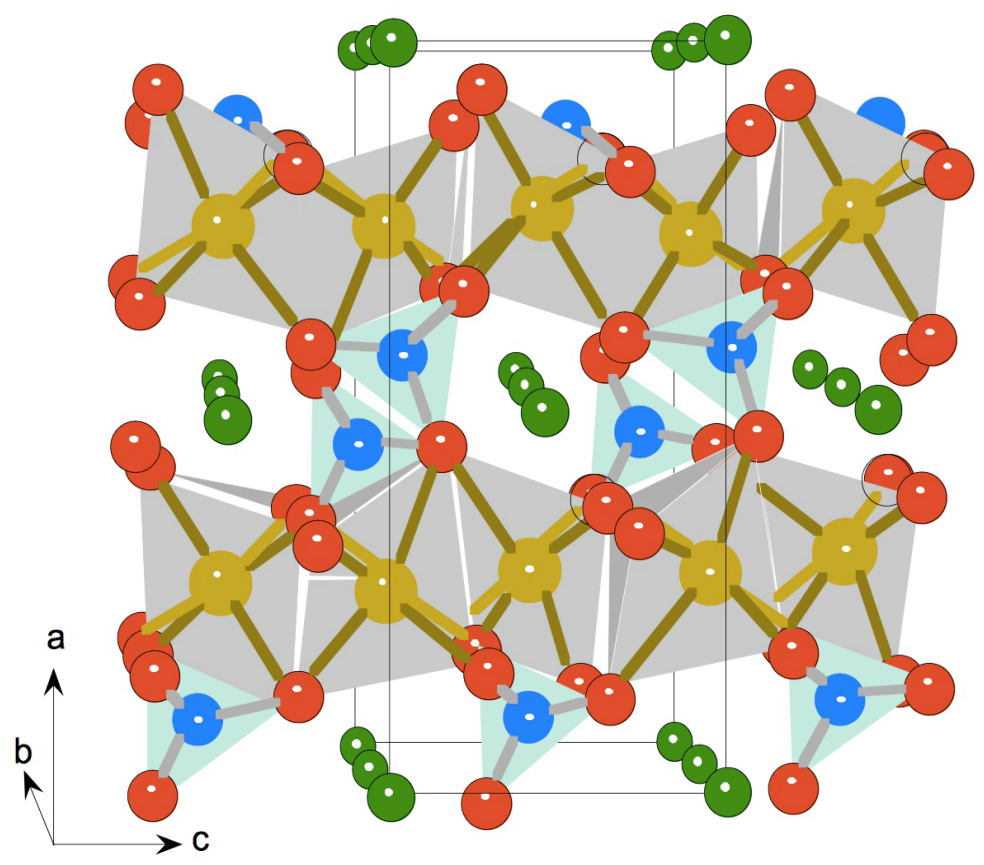

Figure 6 


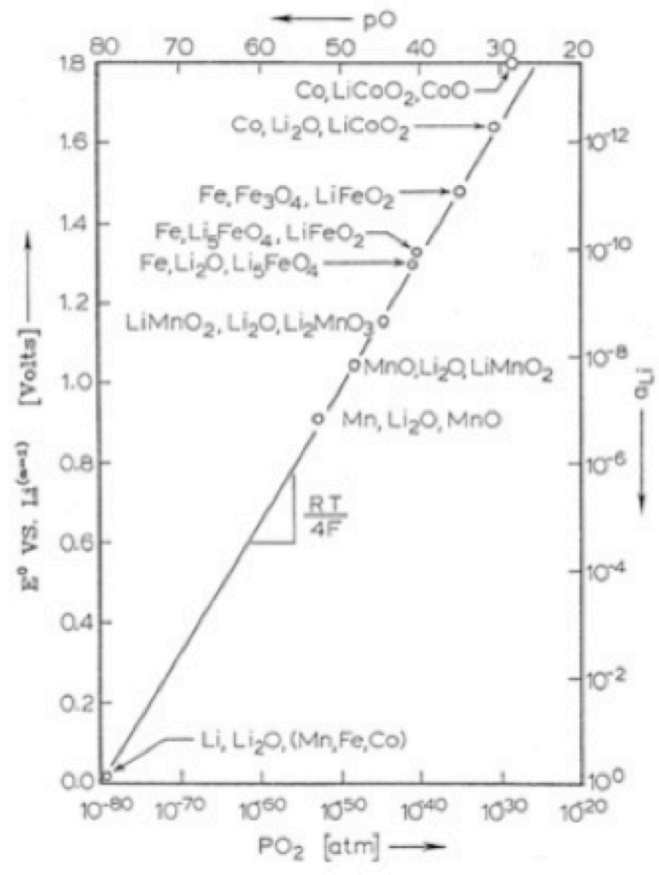

Fig. 7 


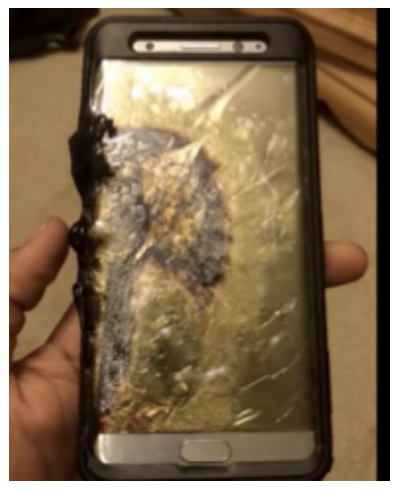

Fig. 8 
